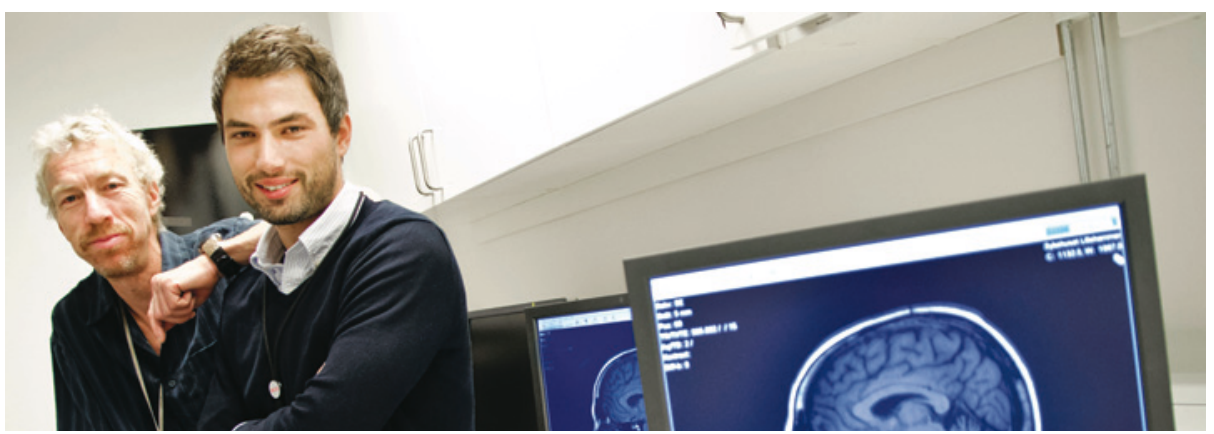

Atle Bjørnerud og Kyrre Eeg Emblem. Foto Ram Eivind Gupta, Oslo universitetssykehus

\title{
Ny metode for avbildning av blodårer i hjernesvulster
}

\section{Forskere fra Oslo universitetssykehus har i samarbeid med forskere fra Harvard University utviklet en ny MR-metode for avbildning av blod- årene i hjernesvulster.}

Ved konvensjonelle radiologiske metoder er det mulig å få et mål på blodvolum og tykkelse på blodårene i en hjernesvulst ved først å injisere et kontrastmiddel under MRopptaket og deretter ta bilder av hvordan midlet passerer gjennom svulsten. Norske forskerne har tatt denne metoden et steg videre ved å undersøke forsinkelsen mellom to uavhengige MR-opptak tatt under kontrastmiddelpassasjen, hvor de to opptakene er tatt samtidig og parallelt (1). Slik får man informasjon om hvilke typer blodårer som finnes i svulsten, hvor bra disse blodårene leverer oksygen til omkringliggende vev og hvor effektive de er til å motta og kvitte seg med blod. Metoden har fått navnet «vessel architectural imaging» (VAI), på norsk «kararkitekturavbildning».

Metoden er testet på pasienter med aggressiv hjernekreft som står på angiogenesehemmende medikamentell behandling. Resultatene viser at man ved hjelp av slike bilder mye tidligere enn ved bruk av konvensjonelle MR-metoder kan forutsi hvilke pasienter som kommer til å respondere på behandlingen (dager eller uker kontra måneder). Hos pasienter som responderer godt, ses vaskulær normalisering i form av færre anormale blodårer, bedret blodstrøm og forbedret oksygenopptak i omkringliggende vev.

- En av de store utfordringene med dagens kreftbehandling er å avklare på forhånd hvilke pasienter som vil ha nytte $\mathrm{av}$ den, sier artikkelens førsteforfatter Kyrre Eeg Emblem ved Oslo universitetssykehus. - Ved hjelp av denne metoden kan man gjøre nettopp det. Hvis det viser seg at en pasient ikke responderer på en bestemt type medikamentell behandling, vil vedkommende potensielt ha brukt opp verdifull tid på uvirksom behandling og kan ofte oppleve ubehagelige bivirkninger, sier han.

- Denne studien er et viktig bidrag til forståelsen av hvordan angiogenesehemmende behandling virker og åpner for nye diagnostiske anvendelsesområder. Vi er allerede i gang med å se på hvordan metoden kan brukes hos pasienter med hjerneslag, sier Eeg Emblem.

\section{Intervensjonssenteret på Rikshospitalet}

Forsker Kyrre Eeg Emblem og professor Atle Bjørnerud har i tett samarbeid med det nevroradiologiske miljøet ved Oslo universitetssykehus, Rikshospitalet, bygd opp gruppen for 'Advanced Neuro Imaging' ved Intervensjonssenteret på sykehuset. De har særlig arbeidet med avansert MR-diagnostikk av hjernesvulster. Forskningen har resultert $i$ en rekke artikler om metodologisk og klinisk bruk av blodstrømsmålinger i hjernesvulster ved hjelp av MR-undersøkelse.

Siden 2009 har gruppen også studert avansert MR under angiogenesehemmende medikamentell behandling i samarbeid med Massachusetts General Hospital og Harvard Medical School i Boston, USA, hvor Eeg Emblem har arbeidet tidligere. Samarbeidet har særlig vært rettet mot miljøet rundt nevroradiologene Bruce Rosen og Gregory Sorensen, som allerede i 1980- og 90-årene var med på å utvikle MR-metoder som i dag brukes i klinisk praksis verden over. Gruppen samarbeider også med Rakesh Jain, som er professor i tumorbiologi og særlig interesserer seg for angiogenesehemmende medikamentell behandling.

\section{Hanne Støre Valeur}

hanne.store.valeur@legeforeningen.no

Tidsskriftet

\section{Litteratur}

1. Emblem KE, Mouridsen K, Bjornerud A et al. Vessel architectural imaging identifies cancer patient responders to anti-angiogenic therapy. Nat Med 2013; 19: 1178-83.
Ordforklaringer

MR-perfusjon: MR-teknikk hvor et kontrastmiddel settes intravenøst og effekten av midlet måles når det passerer gjennom vevet som avbildes. Under undersøkelsen tar man svært mange og like MR-bilder i løpet av et par minutter og måler dermed signalendringen i bildene som følge av kontrastmiddelpassasjen. Dette gir informasjon om blodstrømmen i vevet.

Angiogenesehemmere: En fellesbetegnelse for medikamenter som hemmer nydanningen av blodårer. En kreftsvulst som vokser er fullstendig avhengig av nye blodårer for å få nok næring og oksygen til å fortsette veksten. Målet med behandlingen er å begrense nydanningen.

Vaskulær normalisering: En hypotese innen kreftbehandling med angiogenesehemmere hvor de unormalt store og ineffektive blodårene i en svulst blir mer lik blodårene i friskt vev, både i struktur og funksjon. Kliniske studier viser at denne effekten typisk varer i noen uker eller måneder før blodårene igjen blir unormale. Dette «vinduet» er det optimale tidspunktet for å gi kjemoterapi og strålebehandling. Artikkelen i Nature Medicine støtter opp om hypotesen om vaskulær normalisering dog kun i en undergruppe av pasientene med aggressiv hjernesvulst.

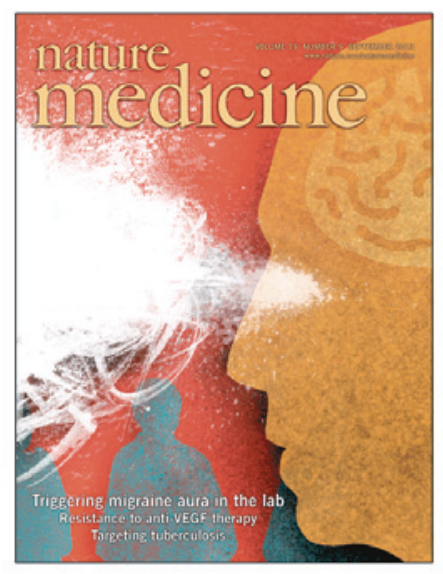

Artikkelen ble publisert i august 2013 i det prestisjetunge tidsskriftet Nature Medicine 